\title{
Genotype and seasonal variation in testes and paired epididymal sperm production among indigenous bull cattle in Mubi Adamawa State, Nigeria
}

\author{
Addass, P.A ${ }^{1}$. \\ ${ }^{1}$ Adamawa State University, Animal Production Department, P.M.B 25 Mubi Adamawa State, \\ Nigeria, Corresponding Author: paaddass@yahoo.com
}

\begin{abstract}
Testicular and paired epididymal sperm production as affected by breed and season were studied among the common Nigerian indigenous bull cattle. Rahaji (RJ) bulls recorded the highest sperm production ability followed by Bunaji (BJ), Sokoto gudali (SG) while Adamawa gudali (AG) had the least. The corresponding paired testes sperm reserve (PTSR) values were; $149.91 \pm 2.68 \times 10^{9}$, $134.69 \pm 2.48 \times 10^{9}, 118.34 \pm 2.59 \times 10^{9}$ and $116.82 \pm 2.55 \times 10^{9}$; for RJ, BJ, SG and AG bulls respective values for right testes sperm reserve (RTSR) were (RJ), $74.72 \pm 1.35 \times 10^{9},(B J), 66.39 \pm 1.25 \times 10^{9}$, (SG), $59.33 \pm 1.31 \times 10^{9}$ and (AG), $58.36 \pm 1.29 \times 10^{9}$; left testes sperm reserve (LTSR) values were $74.20 \pm 1.75 \times 10^{9}, 67.26 \pm 1.61 \times 10^{9}, 57.82 \pm 1.68 \times 10^{9}$ and $58.37 \pm 1.66 \times 10^{9}$,for RJ, BJ, SG, and AG bulls, while for paired epididymal sperm reserve count (PESR) values were (RJ), $301.15 \pm 4.67 \times 10^{9},(B J), 277.72 \pm 4.32 \times 10^{9}$, (SG), $238.70 \pm 4.50 \times 10^{9}$ and (AG), $232.28 \pm 4.44 \times 10^{9}$. significant $(P<0.05)$ season difference on sperm production was observed with the early dry $(E D)$ season favouring sperm production best followed by late dry season (LD) late rain (LR) while early rain (ER) was least. Corresponding PTSR values were $138.69 \pm 2.69 \times 10^{9}, 132.57 \pm 2.60 \times 10^{9}$, $126.70 \pm 2.52 \times 10^{9}$ and $121.45 \pm 2.49 \times 10^{9}$; respective RTRS values were $69.71 \pm 1.36 \times 10^{9}$, $65.94 \pm 1.31 \times 10^{9}, 63.39 \pm 1.27 \times 10^{9}$ and $59.58 \pm 1.26 \times 10^{9}$ while PESR values were $275.93 \pm 4.68 \times 10^{9}$, $269.06 \pm 4.38 \times 10^{9}, \quad 260.09 \pm 4.53 \times 10^{9}$ and $243.88 \pm 4.34 \times 10^{9}$. Sperm production potential was observed to be highest in RJ bulls and least in AG bulls, while early dry season favours best the production of sperm and bulls in the period of early rain had the least.
\end{abstract}

Keywords: Mubi; Genotype; Season; Sperm; Testes; Epididymides.

\section{INTRDUCTION}

Quantification of the sperm production capacity in breeding animals allows for the assessment of the efficiency of spermatogenesis in males kept under different environmental conditions and enhances critical evaluation of effect of season, breed, age, bioclimatic factors, hormones, chemicals and drugs (Amann, 1981). Reproductive success is essential for cow calf producers to be profitable (Hansen, 2006). Hansen (2006) also reported that one percent change in reproductive performance will generate up to 3 times more returns in investment for cow/calf operators when compared to one percent change in production and /or product performance. Increase in the conception rate and subsequent rapid growth of young animals are essential prerequisites for economic gains in animal production. One of the methods to achieve this is to identify a young animal with a high semen producing potential at an early age and season.

\section{MATERIALS AND METHODS}

The most common indigenous bull cattle breeds; Rahaji, Bunaji, Sokoto gudali, and Adamawa gudali kept under different environmental conditions by different farmers were used for the study, bulls were of minimum ages of $1 \frac{1}{2}$ years. Animals were randomly selected as they enter the slaughtering slabs. The previous sexual activities of the bulls were not monitored, because the bulls were kept under extensive system of management from different a farmer (Fulani herds) that constitutes the bulk of cattle in the area. Testes were collected after slaughter, preserved in an ice insulated container and transported directly to the laboratory. Adhering connective tissues and fat coverage were carefully trimmed off. Tunica albuginea carefully removed with minimum loss of parenchyma. Each testis was homogenized in 50mls of saline with antibiotics using a high speed blender operated at full speed for about 2-3 minutes. The homogenate volume was measured after rinsing the blinder container with $20 \mathrm{mls}$ of saline 
solution. $5 \mathrm{mls}$ of the homogenate were transferred to a conical flask and diluted further with $80 \mathrm{mls}$ of saline. This was stored over night at about $5^{\circ} \mathrm{C}$ in a refrigerator to allow for separation of spermatids and spermatozoa from other cells. Sample was then introduced into the neubeur heamocytometer counting chamber. The cells were allowed to stand for 2 minutes to settle down. Spermatozoa was counted using the cell counting device and recorded. Four seasons were prominant in Mubi region which were adopted for the study.

January to March===late dry (LD) season

April to June ====== Early raining (ER) season

July to September==late raining $(L R)$ season

October to December=Early dry (ED) season.

\section{RESULTS AND DISCUSSION}

Significant genotype variability on sperm production among RJ, BJ, SG and AG bulls were evident with $\mathrm{RJ}$ having the highest values on most parameters. On the paired testes sperm reserve (PTSR), values were (RJ) $149.91 \pm 2.68 \times 10^{6}$ followed by (BJ) $134.69 \pm 2.48 \times 10^{6}$, then (SG) $188.34 \pm 2.59 \times 10^{6}$ while (AG) had the least $116.82 \pm 2.55 \times 10^{6}$.

Significant $(\mathrm{P}<0.05)$ breed differences was also pronounced on the right testis sperm reserve (RTSR) and the left testes sperm reserve (LTSR). Rahaji (RJ) bulls had the highest values for the RTSR and LTSR $\left(74.72 \pm 1.35 \times 10^{6}\right.$ and $\left.74.20 \pm 1.75 \times 10^{6}\right)$ followed by the BJ bulls $\left(66.39 \pm 1.25 \times 10^{6}\right.$ and $\left.67.26 \pm 1.61 \times 10^{6}\right)$ while the SG and AG bulls both had similar least values for the RTSR and LTSR $\left(59.33 \pm 1.31 \times 10^{6}\right.$, $58.36 \pm 1.29 \times 10^{6}$ and $57.82 \pm 1.68 \times 10^{6}$, $58.37 \pm 1.66 \times 10^{6}$ ) (Table 1).

Table 1: Means \pm SE by breed of testes and paired Epididymal sperm reserve of some indigenous bull cattle.

\begin{tabular}{|c|c|c|c|c|c|c|c|c|c|c|}
\hline Variable & $\mathrm{N}$ & $\operatorname{PTSR}\left(\times 10^{9}\right)$ & $\operatorname{RTSR}\left(\times 10^{9}\right)$ & $\operatorname{LTSR}\left(\times 10^{9}\right)$ & $\operatorname{PESR}\left(\times 10^{9}\right)$ & $\operatorname{PCSR}\left(\times 10^{9}\right)$ & $\operatorname{PCoSR}\left(\times 10^{9}\right)$ & $\operatorname{PCaSR}\left(\times 10^{9}\right)$ & $\mathrm{SC}(\mathrm{cm})$ & FPEC \\
\hline Season & & * & ** & NS & * & NS & 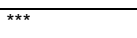 & NS & NS & * \\
\hline LD & 48 & $132.57 \pm 2.60^{\mathrm{ab}}$ & $65.94 \pm 1.31^{a}$ & $65.53 \pm 1.69^{\mathrm{a}}$ & $260.09 \pm 4.53^{b}$ & $111.85 \pm 2.15^{\mathrm{a}}$ & $20.09 \pm 1.23^{\mathrm{a}}$ & $128.57 \pm 2.42^{\mathrm{a}}$ & $30.25 \pm 0.15^{a}$ & $13.64 \pm 0.69^{\mathrm{a}}$ \\
\hline ER & 49 & $121.45 \pm 2.49^{c}$ & $59.58 \pm 1.26^{\mathrm{c}}$ & $61.05 \pm 1.62^{\mathrm{a}}$ & $243.88 \pm 4.34^{c}$ & $108.57 \pm 2.06^{\mathrm{a}}$ & $13.58 \pm 1.18^{b}$ & $121.96 \pm 2.32^{\mathrm{a}}$ & $29.99 \pm 0.14^{\mathrm{a}}$ & $16.62 \pm 0.66^{\mathrm{a}}$ \\
\hline LR & 50 & $126.70 \pm 2.52^{\mathrm{b}}$ & $63.39 \pm 1.27^{\mathrm{b}}$ & $62.97 \pm 1.64^{\mathrm{a}}$ & $269.06 \pm 4.38^{a}$ & $115.88 \pm 2.08^{\mathrm{a}}$ & $23.19 \pm 1.19^{\mathrm{a}}$ & $127.60 \pm 2.34^{\mathrm{a}}$ & $30.39 \pm 0.14$ & $11.87 . \pm 0.66^{\mathrm{bc}}$ \\
\hline ED & 42 & $138.69 \pm 2.69^{\mathrm{a}}$ & $69.71 \pm 1.36^{\mathrm{a}}$ & $67.82 \pm 1.75^{\mathrm{a}}$ & $275.93 \pm 4.68^{\mathrm{a}}$ & $121.27 \pm 2.22^{\mathrm{a}}$ & $20.27 \pm 1.27^{\mathrm{a}}$ & $134.06 \pm 2.50^{\mathrm{a}}$ & $30.40 \pm 0.15$ & $10.92 \pm 0.71^{c}$ \\
\hline
\end{tabular}

$\mathrm{N}=$ number of observations, ${ }^{*}=\mathrm{P}, 0.05,{ }^{* *}=\mathrm{P}<0.01,{ }^{* * *}=\mathrm{P}<0.001, \mathrm{PTSR}=\mathrm{Paired}$ Testes Sperm Reserve, RTSR=Right Testes Sperm Reserve, LTSR=Left Testes Sperm Reserve, PESR=Paired epididymal Sperm reserve, PCSR=Paired Carpot Sperm Seserve, PCoSR=Paired Corpus Sperm Reserve, PCaSR=Paired Cauda Sperm Reserve, SC=scrotal circumference, FPEC=Feacal Parasitic Egg Count, AG=Adamawa Gudali, BJ=Bunaji, RJ=Rahaji, SG=Sokoto Gudali.

Note: Means for groups in homogenous subsets and with same Superscript(s) are statistically similar.

Significant $(P<0.001)$ genotype differences on paired epididymedes sperm reserve (PESR) was recorded. Rahaji had highest values $\left(301.15 \pm 4.67 \times 10^{6}\right)$ followed by BJ $\left(277.72 \pm 4.32 \times 10^{6}\right)$ while similar least values were found on SG and AG $\left(238.70 \pm 4.50 \times 10^{6}\right.$ and $232.28 \pm 4.44 \times 10^{6}$ ).

Significant $(P<0.01)$ breed differences on paired carput sperm reserve (PCSR) and paired corpus sperm reserve (PCoSR) were evident among the bulls. On PCSR, RJ had the highest $\left(132.67 \pm 2.22 \times 10^{6}\right)$ next by BJ $\left(118.68 \pm 2.05 \times 10^{6}\right)$ while least and similar values were on SG $\left(103.63 \pm 2.14 \times 10^{6}\right)$ and AG $\left(103.74 \pm 2.11 \times 10^{6}\right)$. On PCoSR however BJ had highest $\left(21.95 \pm 1.18 \times 10^{6}\right)$ followed by RJ $\left(20.30 \pm 1.27 \times 10^{6}\right)$ while SG and AG had similar and least values $\left(17.46 \pm 1.23 \times 10^{6}\right.$ and $16.78 \pm 1.21 \times 10^{6}$ ).

Depicted on paired cauda sperm reserve (PCaSR) was a significant $(P<0.001)$ breed differences. Rahaji had the highest $\left(148.18 \pm 2.49 \times 10^{6}\right)$ then $\mathrm{BJ}$ $\left(135.19 \pm 2.31 \times 10^{6}\right)$ while similar and least values were recorded on SG $\left(117.47 \pm 2.40 \times 10^{6}\right)$ and AG $\left(111.94 \pm 2.37 \times 10^{6}\right)$.

Significant (P0.01) breed variation was noticed on scrotal circumference (SC). Highest value $(31.45 \pm 0.15 \mathrm{~cm})$ was recorded on RJ while similar values were found among $B J(30.22 \pm 0.14 \mathrm{~cm})$, SG $(29.96 \pm 0.15 \mathrm{~cm})$ and $A G(29.59 \pm 0.14 \mathrm{~cm})$ bulls. 
Significant $(P<0.001)$ breed difference on feacal parasitic egg count (FPEC) was evident. Sokoto Gudali (SG) had the highest $(18.21 \pm 0.68)$ followed by RJ (16.35 \pm 0.71$)$ while BJ $(10.21 \pm 0.66)$ and AG $(9.57 \pm 0.67)$ had similar and least values.

The significant genetic group differences observed on gonadal and extra gonadal sperm reserve count in this study has been consistent with the findings of Salau-Dauda Shoyinka (1983); Tegegne et al ., (1992b) and Britto et al., (2002 and 2006) who reported breed variability in gonadal and extra gonadal sperm reserve in Bos indicus genetic group. Gonadal sperm production has been reported to be dependent on the amount of sperm producing testicular parenchyma tissue which is mainly influenced by nutrition and breed (Tegegne et al., $1992 \mathrm{a}$ and $\mathrm{b}$ ). increased sperm production has been reported to be associated with increased testicular weight and volume, scrotal circumference, testicular vascular cones (TVC), fat cover and scrotal surface temperature (SST) top to bottom gradient (Britto et al., 2002). Positive correlation was also reported between sperm production and scrotal testicle shape (Stephen, 2002) and body condition score (Ikhatua and Olayiwole, 1982).
Depicted in this study also was genotype variability due to feacal parasitic egg count (FPEC) which might be due to breed susceptibility and/or malnutrition that usually predispose animals to helminth infections. The finding $s$ is in line with the report of Sha-Fischer and Raph Say, (1989) who reported that helminth infection are insidious diseases that are confused with nutritional problem which normally predispose animals to parasitic infections. Sokoto Gudali was found to be vulnerable to parasitic infection followed by RJ, BJ, and AG. Shown in (Table 2) is the effect of season on sperm production on the common bull breeds in the area of study. Significant $(P<0.05)$ seasonal difference was pronounced indicating early dry (ED) season favouring paired testes sperm reserve ((PTSR) highest $\left(138.69 \pm 2.69 \times 10^{9}\right)$ followed by the followed by (LD) $\left(132.57 \pm 2.60 \times 10^{9}\right)$ then late rain $(L R)\left(126.70 \pm 2.52 \times 10^{9}\right)$ while early rain (ER) had the least $\left(121.45 \pm 2.49 \times 10^{9}\right)$.

Significant $(P<0.01)$ seasonal effect on right testes sperm reserve (RTSR) differences was also evident. Early dry $\left(69.71 \pm 1.36 \times 10^{9}\right)$ season had the highest value followed by the LD $\left(65.94 \pm 1.31 \times 10^{9}\right)$ then LR $\left(63.39 \pm 1.27 \times 10^{9}\right)$ while least value was recorded during the ED $\left(59.58 \pm 1.26 \times 10^{9}\right)$.

Table 2: Means \pm SE by season of Testes and paired epididymal sperm reserve of some indigenous bull cattle

\begin{tabular}{|c|c|c|c|c|c|c|c|c|c|c|}
\hline Variable & $\mathrm{N}$ & $\operatorname{PTSR}\left(\times 10^{9}\right)$ & $\operatorname{RTSR}\left(\times 10^{9}\right)$ & $\operatorname{LTSR}\left(\times 10^{9}\right)$ & $\operatorname{PESR}\left(\times 10^{9}\right)$ & $\operatorname{PCSR}\left(x 10^{9}\right)$ & $\operatorname{PCoSR}\left(\times 10^{9}\right)$ & $\operatorname{PCaSR}\left(\times 10^{9}\right)$ & $\mathrm{SC}(\mathrm{cm})$ & FPEC \\
\hline Season & & * & ** & NS & * & NS & $* \star *$ & NS & NS & * \\
\hline LD & 48 & $132.57 \pm 2.60^{\mathrm{ab}}$ & $65.94 \pm 1.31^{a}$ & $65.53 \pm 1.69^{\mathrm{a}}$ & $260.09 \pm 4.53^{b}$ & $111.85 \pm 2.15^{\mathrm{a}}$ & $20.09 \pm 1.23^{\mathrm{a}}$ & $128.57 \pm 2.42^{\mathrm{a}}$ & $30.25 \pm 0.15^{a}$ & $13.64 \pm 0.69^{\mathrm{a}}$ \\
\hline ER & 49 & $121.45 \pm 2.49^{c}$ & $59.58 \pm 1.26^{\mathrm{c}}$ & $61.05 \pm 1.62^{\mathrm{a}}$ & $243.88 \pm 4.34^{\mathrm{C}}$ & $108.57 \pm 2.06^{\mathrm{a}}$ & $13.58 \pm 1.18^{\mathrm{b}}$ & $121.96 \pm 2.32^{\mathrm{a}}$ & $29.99 \pm 0.14^{\mathrm{a}}$ & $16.62 \pm 0.66^{\mathrm{a}}$ \\
\hline LR & 50 & $126.70 \pm 2.52^{\mathrm{b}}$ & $63.39 \pm 1.27^{b}$ & $62.97 \pm 1.64^{\mathrm{a}}$ & $269.06 \pm 4.38^{a}$ & $115.88 \pm 2.08^{\mathrm{a}}$ & $23.19 \pm 1.19^{\mathrm{a}}$ & $127.60 \pm 2.34^{\mathrm{a}}$ & $30.39 \pm 0.14$ & $11.87 . \pm 0.66^{\mathrm{bc}}$ \\
\hline ED & 42 & $138.69 \pm 2.69^{\mathrm{a}}$ & $69.71 \pm 1.36^{a}$ & $67.82 \pm 1.75^{\mathrm{a}}$ & $275.93 \pm 4.68^{\mathrm{a}}$ & $121.27 \pm 2.22^{\mathrm{a}}$ & $20.27 \pm 1.27^{\mathrm{a}}$ & $134.06 \pm 2.50^{\mathrm{a}}$ & $30.40 \pm 0.15$ & $10.92 \pm 0.71^{c}$ \\
\hline
\end{tabular}

$\mathrm{N}=$ number of observation, $\mathrm{NS}=$ Not significant, ${ }^{*}=\mathrm{P}<0.05,{ }^{* *}=\mathrm{P}<0.01,{ }^{* *} \mathrm{P}<0.001, \mathrm{LD}=$ late dry, $\mathrm{ER}=$ early rain, $\mathrm{LR}=\mathrm{late}$ rain $\mathrm{ED}=\mathrm{early}$ dry. PTSR=Paired Testes Sperm Reserve, RTSR=Right Testes Sperm Reserve, LTSR=Left Testes Sperm Reserve, PESR=Paired epididymal Sperm reserve, PCSR=Paired Carpot Sperm Seserve, PCoSR=Paired Corpus Sperm Reserve, PCaSR=Paired Cauda Sperm Reserve, $\mathrm{SC}=$ scrotal circumference, FPEC=Feacal Parasitic Egg Count.

Note: Means for groups in homogenous subsets and with same Superscript(s) are statistically similar

Significant seasonal variation was observed on paired epididymal sperm reserve (PESR). Early dry season had the highest $\left(275.93 \pm 4.68 \times 10^{9}\right)$ values, next was the LR $\left(269.06 \pm 4.38 \times 10^{9}\right)$ then LD $\left(260.09 \pm 4.53 \times 10^{9}\right)$ while ER had the least $\left(243.88 \pm 4.34 \times 10^{9}\right)$.

Seasonal differences $(P<0.001)$ was also observed on paired corpus sperm reserve (PCoSR) with ED $\left(20.27 \pm 1.27 \times 10^{9}\right) \quad$ LR $\left(23.19 \pm 1.19 \times 10^{9}\right)$ and LD $\left(20.09 \pm 1.23 \times 10^{9}\right)$ having similar highest values while
ER $\left(13.58 \pm 1.18 \times 10^{9}\right)$ had the least value. A significant seasonal difference was depicted on feacal parasitic egg count (FPEC). Early rainy season $(16.62 \pm 0.66)$ and LD $(13.64 \pm 0.69)$ had similar and highest values followed by LR $(11.87 \pm 0.66)$ while ED $(10.92 \pm 0.71)$ had the least values.

Significant seasonal variation on sperm reserve count observed in this study agreed with what was reported by Igboeli et al., (1987) who reported that in the tropics, the rainy season is associated with conditions well suited to accepted levels of bull sperm output 
and quality which he said was due to abundance of lush pasture and low temperature. The dry season however is associated with poor quality and quantity of feed, high ambient temperature which influences feed intake; as a result affects bull semen production and quality (Tegegne, et al., 1992a). Egbunike, et al., (1985) also reported seasonal effects on reproductive function in bull in the tropics to be related to nutrition, ambient temperature, age and pathological factors. Tegegne, et al., (1992b) however reported that the effects of these factors on reproduction vary with breed and also husbandry practices.

\section{REFERENCES}

Amann, R.P.(1981). A critical review of methods for evaluation of spermatogenesis from seminal characteristics. Journal of Andiology, 2: 37-58.

Brito, L.F., Silva, A.E., Deragon, L.A and Kastelic, J.P. (2002). Effect of age and genetic group on characteristics of the scrotum testes and testicular vascular cones and sperm production and semen quality in Al bulls. Thenogenology, (2002).

Brito, L.F., Silva, A.E., Rodrigues, L.H., Viera, F.V., Deragon, L.A and Kastelic, J.P (2006). Effects of age and environmental factors on semen production and semen quality of Austrian Simmental bulls. Animal Reproduction Science, 2006.

Egbunike, C.N., Togun, V.A and Againg, E.A (1985). World Review of Animal production. 21: 11-17.

Hansen, G.R. (2006) Managing bull fertility in beef cattle herds. AN153 series of animal Science Department, Florida. Cooperative extension service institute of food and Agriccutural Sciences. University of Florida (2006). EDIS website at http//edis.afas.ufl.edu.osterhoff (1990). In improving reproduction in farm animals. I.N. Wiltbank. Class notes. Aniamal Science 510, 1990. Brigham Young University. P 382.

Igboeli, G., Nwakalar, L.N., Orji, B.I and Onuwa G.I (1987). Seasonal variation in the semen characteristics in Muturu (Bos branchejorous) bulls. Animal Reproduction Science. 14 (1): 31-38.

Ikhatua, U.I and Olayiwole, M.B (1982). Seasonal effects on performance of of feed lot bulls. Journal of Animal Production Research,2 (2): 99-111.

Salau-Daudu, C. and Shoyinka, V (1983). Scrotal circumference, daily sperm production and epididymal spermatozoa of the indigenous Bunaji and Bokoloji bulls in Nigeria. British Veterinary journal, 139: 467470.

Shah-Fischer, M. and Raph Say, R. (1989). Manual of Tropical Parastology, CAB International, Willingford, Ox on Ox 108 DE UK., English Edition.

Stephen, B.B. (2002). Age at puberty and scrotal circumference are important factors to bull selection. Webmaster@cattletoday.com.

Tegegne, A., Enstwistle, K.W and Mukasa-Mugarwa, E (1992a). Gonodal and extragonodal sperm reserves and testicular histometrics characteristics in zebu and cross breed bulls. Effect of dry season nutritional supplementation. Animal reproduction science, 29: (12): 25-33.

Tegegne, A., Enstwistle, K.W and Mukasa-Mugarwa, E (1992b). Gonodal and extragonodal sperm reserves in small east African Zebu (Bos Indicus) bulls in Ethiopia. Tropical Animal Health production (1992 Nov): 24:(4): 216-222. 